\title{
Feeding spectra and activity of the freshwater crab Trichodactylus kensleyi (Decapoda: Brachyura: Trichodactylidae) at La Plata basin
}

Verónica Williner ${ }^{1,2^{*}}$, Debora Azevedo Carvalho ${ }^{1}$ and Pablo A Collins ${ }^{1,3}$

\begin{abstract}
Background: In inland water systems, it is important to characterize the trophic links in order to identify the 'trophic species' and, from the studies of functional diversity, understand the dynamics of matter and energy in these environments. The aim of this study is to analyze the natural diet of Trichodacty/us kensleyi of subtropical rainforest streams and corroborate the temporal variation in the trophic activity during day hours.

Results: A total of 15 major taxonomic groups were recognized in gut contents. The index of relative importance identified the following main prey items in decreasing order of importance: vegetal remains, oligochaetes, chironomid larvae, and algae. A significant difference was found in the amount of full stomachs during day hours showing a less trophic activity at midday and afternoon. The index of relative importance values evidenced the consumption of different prey according to day moments. Results of the gut content indicate that $T$. kensleyi is an omnivorous crab like other trichodactylid species. Opportunistic behavior is revealed by the ingestion of organisms abundant in streams such as oligochaetes and chironomid larvae. The consumption of allochthonous plant debris shows the importance of this crab as shredder in subtropical streams. However, the effective assimilation of plant matter is yet unknown in trichodactylid crabs.
\end{abstract}

Conclusions: This research provides knowledge that complements previous studies about trophic relationships of trichodactylid crabs and supported the importance of $T$. kensleyi in the transference of energy and matter from benthic community and riparian sources to superior trophic levels using both macro- and microfauna.

Keywords: Decapoda; Omnivorous crab; Shredder; Subtropical forest; Streams

\section{Background}

The trophic ecology of brachyuran crabs has been widely studied in marine crabs probably because of their ecological and economic importance (Wear and Haddon 1987; Freire 1996; Cannicci et al. 1996; Mantelatto and Petracco 1997; Balasubramanian and Suseelan 1998; Frick et al. 2001; Mantelatto and Christofeletti 2001; Josileen 2011). However, among freshwater crabs, the research effort in this area is more recent with little emphasis in trichodactylid crabs (Collins et al. 2007; Carvalho et al. 2013a; Williner and Collins 2013; Pirela

\footnotetext{
* Correspondence: vwilliner@inali.unl.edu.ar

${ }^{1}$ Instituto Nacional de Limnología (CONICET-UNL), Ciudad Universitaria, Paraje El Pozo s/n, Santa Fe 3000, Argentina

${ }^{2}$ Facultad de Humanidades y Ciencias (UNL), Ciudad Universitaria, Paraje El pozo s/n, Santa Fe 3000, Argentina

Full list of author information is available at the end of the article
}

and Rincón 2013). Knowledge about trophic ecology aspects of any species is essential to understand the nutritional requirements and how species interact with the environment and with other organisms. In inland water systems, it is important to characterize the trophic links in order to identify the 'trophic species' and, from the studies of functional diversity, understand the dynamics of matter and energy in these environments (Woodward 2009).

Trichodactylidae is a family of crabs associated to river basins of Center and South America with exception of the Pacific slope rivers (Magalhães 2003; César et al. 2004). The genus Trichodactylus is composed of nine species in the Neotropical region of which almost $50 \%$ inhabits aquatic environments of Argentina. Among these species, Trichodactylus kensleyi has a geographical distribution associated to the Paraná and 
Uruguay Rivers and restricted to the subtropical forest of Argentina, Paraguay, Brazil, and Uruguay (Magalhães 2003). Capture records of this freshwater crab in Argentina range from 200 to $600 \mathrm{~m}$ above sea level in streams of subtropical rainforest, where they can be trapped in the bottom under rocks, clay, and sand (Collins 2005).

Trophic ecology studies (e.g., behavior, feeding habits) on trichodactylid crabs in Argentina have reported a variety of aquatic environments (e.g., in subtropical savannah and alluvial valley of template rivers) and feeding habits (Williner and Collins 2002; Collins et al. 2006; Collins et al. 2007; Williner and Collins 2013; Carvalho et al. 2013a, 2013b). In general, these crustaceans are omnivorous with a wide trophic spectrum that ranges from algae and plant remains to insect larvae and even vertebrates (Collins et al. 2006). In this way, they can play a functional role as shredders and predators. On the other hand, they are prey of many vertebrates like fishes, amphibians, reptiles, birds, and mammals (Bonetto et al. 1963; Beltzer 1983; 1984; Beltzer and Paporello 1984; Lajmanovich and Beltzer 1993; Massoia 1976; Bianchini and Delupi 1993; López et al. 2005), emphasizing the importance of this species in aquatic systems.

Despite the ecological significance of trichodactylid crabs, there are little information about the biology and ecology of some species such as T. kensleyi. This endemic distribution and the progressive habitat modification where they occur make any research about this decapod important. Considering this background, the aim of this study is to analyze the natural diet of T. kensleyi of subtropical rainforest streams and verify the daily variation in the feeding activity during light hours.

\section{Methods}

\section{Study area}

The study was conducted in the subtropical rainforest of southern South America (Misiones Province, Argentina), in streams with drainage to the Uruguay and Paraná Rivers such as Zamambay, El Trébol, Cuña Pirú, and Yaguarundí streams (Figure 1). This area covers the subregion of Paranaense forest and is characterized by great biological diversity, unique in southern South America (Myers et al. 2000). It is located in the upper zone of the Paraná basin. In the west, it is limited by the Paraná River, in the east by the Uruguay, San Antonio, and Pepirí Guazú Rivers, and in the north by the Iguazú River (Figure 1). This region has a subtropical climate without drought season with an annual rainfall between 1,600 and 2,000 $\mathrm{mm}$ and an annual average temperature of $20^{\circ} \mathrm{C}$. Environmental oscillations are mainly related to the rainfall regime. The socalled gallery forest bordered the streams' shoreline with dominance of hydrophilic vegetation. The streams of sampling are shallow, have high transparency and water velocity, and have scarce submerged vegetation, and the bottom is composed of clay, sand, and rocks. The input of organic matter in these streams mainly comes from allochthonous source.

\section{Field sampling}

Crabs were collected and separated from the bottom and below rocks manually and with a hand net with a pore size of $500 \mu \mathrm{m}$. The crabs were placed in containers with cold water and ice to reduce their metabolism, to inhibit maceration by the gastric mill, and to avoid regurgitation. After a few minutes, the crabs were fixed by adding $96 \%$ alcohol to the cold water. This humane way of sacrificing these animals was used in the absence of an approved ethical procedure in the jurisdiction where the study was carried out. The same procedure was repeated in each stream during the light hours of a day (8:00, 12:00, 15:00, and 19:00). Crabs of the same sample hour were pooled to fit the statistical analysis. To characterize the water quality, some physicochemical parameters such as temperature, dissolved oxygen, $\mathrm{pH}$, and conductivity were measured with digital sensors (HANNA HI 98129, HANNA instruments, Woonsocket, RI, USA).

\section{Laboratory analysis}

The cephalothorax width $(\mathrm{CW})$, considered as the length between postorbital spines, was measured with a caliper under a stereomicroscope to the nearest $0.01 \mathrm{~mm}$, and the sex was determined by the presence of the masculine appendix and abdominal characteristics (Lopretto 1976). To acquire the degree of stomach fullness, the crabs were dissected, the stomach was removed, and the muscular remains were cleaned to facilitate the visualization of the gut content. A subjective scale from 1 to 5 (1: empty, 2: $1 \%$ to $25 \%$ full, $3: 25 \%$ to $50 \%$ full, $4: 50 \%$ to $75 \%$ full, and 5: $75 \%$ to $100 \%$ ) was used to categorize the total stomach repletion. Then, each stomach was opened and the content placed in an Eppendorf tube with alcohol 96\% and stained with erythrosine. After at least 1 day, contents were mounted on slides on a drop of glycerol and examined under a compound microscope with $\times 100$ and $\times 400$ of magnification. Prey items were identified as precisely as possible.

\section{Data analysis}

The minimum number of crabs needed to reach a representative sample of the trophic diversity was estimated for every sample hour by the Chao estimation of species richness (Colwell 2013). The index of relative importance (IRI) was applied to analyze gut contents with the following formula: $\operatorname{IRI}=\left(C_{\mathrm{v}}+C_{\mathrm{n}}\right) \times F$ (Pinkas et al. 1971), where $C_{\mathrm{v}}$ is the volumetric content of prey, $C_{\mathrm{n}}$ is the number of prey, and $F$ is the frequency of occurrence of each prey item. The volume of items was calculated by approximation to a geometric shape or water displacement or transformed from values obtained from 


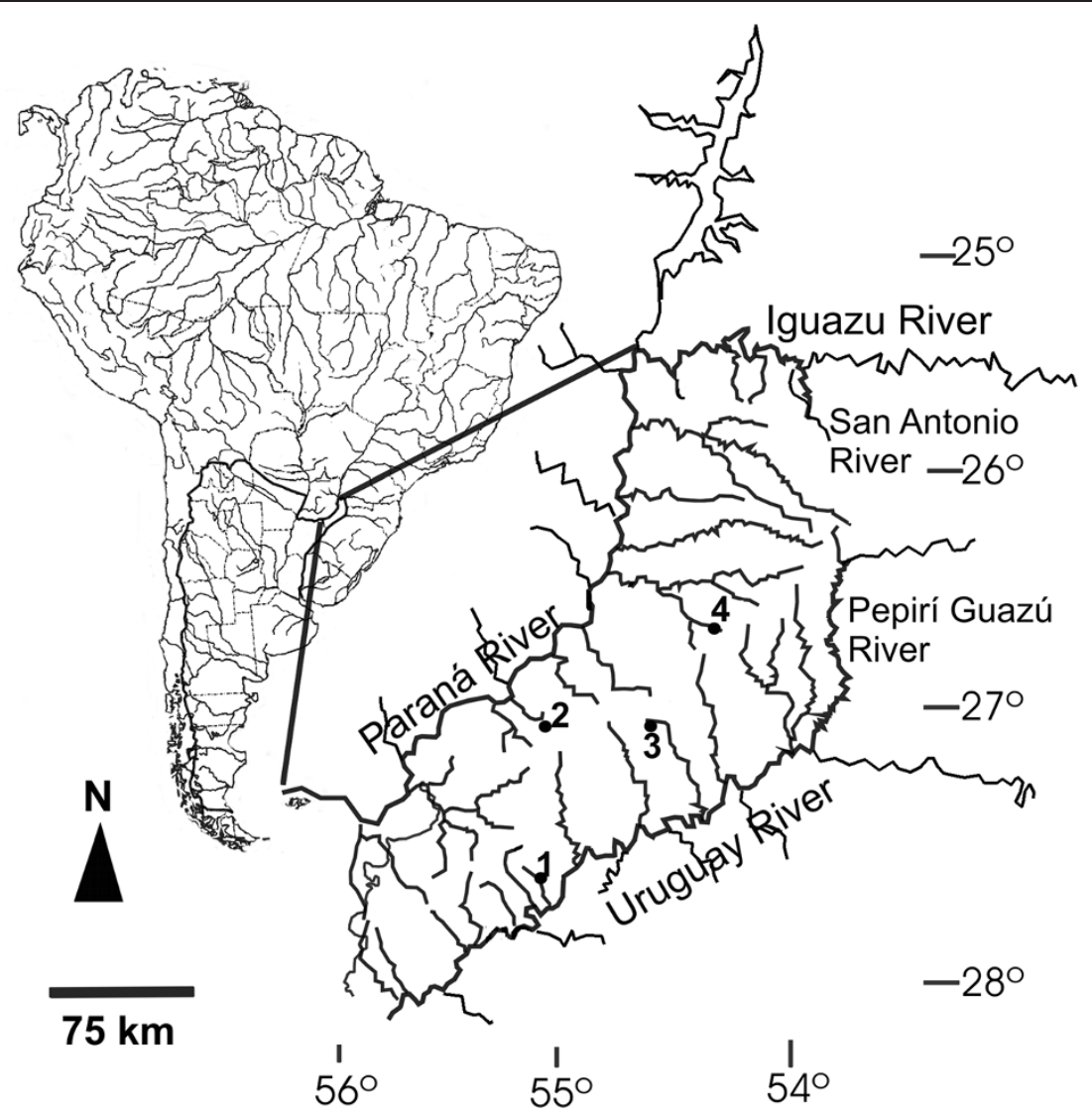

Figure 1 Schematic map of the localities where specimens of Trichodactylus kensleyi were captured. 1) Zamambay, 2) Cuña Pirú, 3) El Trébol, and 4) Yaguarundí.

the literature (Edmonson and Winberg 1971; Dumont et al. 1975; Ruttner-Kolisko 1977; Williner 2007). In order to compare IRI values of each sample hour among food items, a non-parametric analysis of variance (Kruskal-Wallis) was performed. The degree of stomach repletion was compared for each sample hour using a non-parametric analysis of variance (Kruskal-Wallis) while the cephalothorax width was tested for significance with a parametric analysis of variance (Kruskal-Wallis) (Zar 1996).

\section{Results}

Physicochemical parameters of water in the sampling period showed average values of $21.7^{\circ} \mathrm{C} \pm 2.28^{\circ} \mathrm{C}$ for temperature, $44.8 \pm 15.24 \mu \mathrm{S}$ for conductivity, $7.2 \pm 0.3$ for $\mathrm{pH}$, and $5.5 \pm 0.8 \mathrm{mg} / \mathrm{l}$ for dissolved oxygen. The proportion of males and females was $50 \%$ and $40.5 \%$, respectively. The highest sex ratio (males/females) was recorded during the warmest time of the day (15:00) while during the midday and sunset, these values were close to one. The averages of cephalothorax width were similar (ANOVA, $F=0.306, p=0.821$ ) in all sample hours with a maximum of $21.5 \mathrm{~mm}$ and a minimum of $4.7 \mathrm{~mm}$ (Table 1).
The degree of stomach repletion was statistically different throughout the day (Kruskal-Wallis (KW), $H=$ 30.28, $p=5.54 \times 10^{-7}$ ), and the stomach fullness reaches the highest values at the afternoon and dawn period (Figure 2). The minimum number of stomachs necessary for the analysis was quite similar throughout the day to reach a representative sample. However, the content diversity is greater in the evening and morning than in the midday and afternoon (Figure 3).

The analyses of stomach content indicate that this crab fed on benthic organisms, riparian vegetation remains, and drifting terrestrial fauna, with a wide trophic spectrum (Table 2). Food was found completely shredded, and grains of sand were observed in the stomach content. The most important food items were autotrophic organisms with predominance of vegetation remains. Macroinvertebrates such

Table 1 Sex ratio (males/females) and CW (mean and standard deviation) of $T$. kensleyi at each sample hour

\begin{tabular}{lllll}
\hline & $\mathbf{0 8 : 0 0}$ & $\mathbf{1 2 : 0 0}$ & $\mathbf{1 5 : 0 0}$ & $\mathbf{1 9 : 0 0}$ \\
\hline $\mathrm{M} / \mathrm{F}$ & 1.5 & 0.9 & 3 & 0.9 \\
$\mathrm{CW}(\mathrm{mm})$ & $12.53 \pm 3.78$ & $11.92 \pm 4.13$ & $12.92 \pm 5.89$ & $11.43 \pm 4.91$ \\
\hline
\end{tabular}




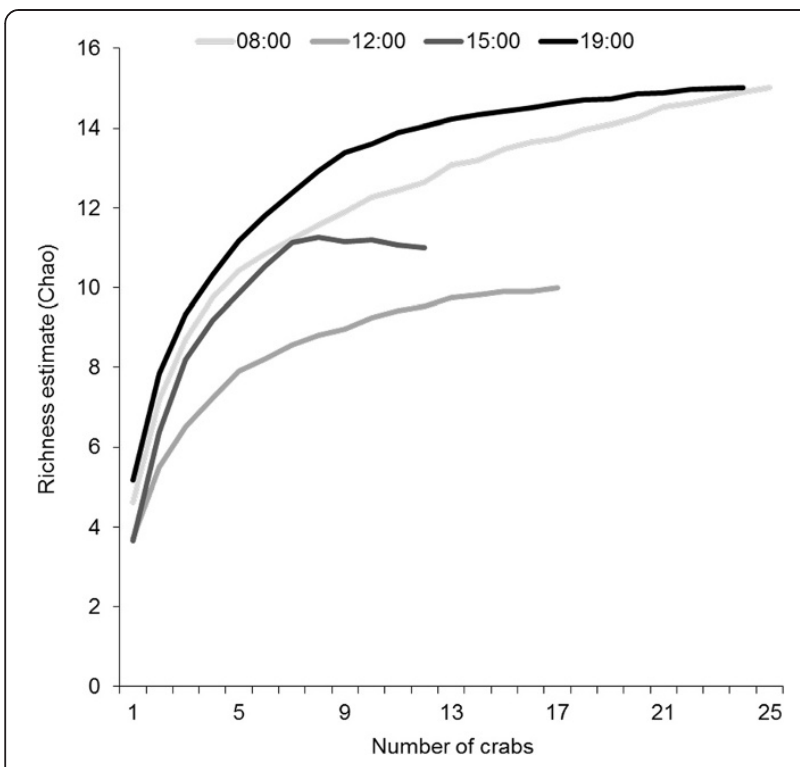

Figure 2 Chao estimation of species richness of Trichodactylus kensleyi at each sample hour.

as Oligochaeta and Chironomidae larvae had also a high IRI (Figure 4).

The analysis of IRI values evidenced statistical differences among food items (KW, $H=41.8, p=0.0001$; Figure 5). The presence of unicellular algae, diatoms, ostracods, and insect larvae in the stomach content of crabs caught at 8:00 and 12:00 evidenced the consumptions of these prey during the early morning until the midday. A reverse pattern was observed with filamentous algae, fungus, cladocerans, adult insects, and arachnids, which were more important in the diet in the last day hours. Microorganisms such as protozoans, rotifers, copepods, and also oligochaetes were preyed with more intensity during the afternoon. On the other hand, chironomid larvae and vegetal remains had two peaks of consumptions: one in the morning and the other in the evening.

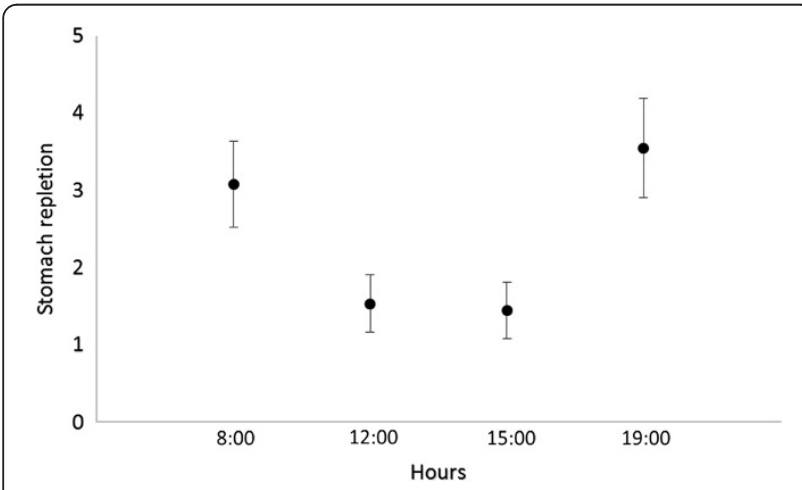

Figure 3 Average value of stomach repletion indexes of Trichodactylus kensleyi determined at each sample hour.

\section{Discussion}

The analysis of gut content of $T$. kensleyi revealed that this crab shares similar aspects to the diet of other crabs of the same genus and family. Trichodactylid crabs are reported to have opportunistic and omnivorous feeding habits, with a high consumption of vegetal matter, but animal items represent an important fraction of the trophic spectrum (Williner and Collins 2002; Collins et al. 2006; Pirela and Rincón 2013; Williner and Collins 2013). The presence of omnivorous organisms can contribute to understand the dynamics of aquatic systems and provide elements to analyze the stability of these species (Long et al. 2011; Kratina et al. 2012).

In the present study, it is observed that animals of low movement such as oligochaetes and quironomid larvae constituted the most important items in the diet of this crab species. On the other hand, the presence of algae was relevant in the gut content while microorganisms like rotifers, protozoans, and microcrustaceans had a minor relative importance. These results conform with the previous finding of Williner and Collins (2013) who reported that a crab of the same genus, $T$. borellianus, had a high relative importance of oligochaetes and insect larvae in the diet. However, in contrast to the generalizations made by Burress et al. (2013) that 'trichodactylids do not appear to engage in carnivory', it is evident in this study and in the previous literature that trichodactylid species often use animal resources, hunting them and eating dead animals (Williner and Collins 2002; Collins et al. 2006; Carvalho et al. 2013a, Pirela and Rincón 2013; Williner and Collins 2013).

Despite the importance of animal items, the prominence of vegetal component in the diet of trichodactylid crabs is indubitable. In the case of T. kensleyi, this type of food is provided mainly from allochthonous source. This fact open two main issues of discussion: the importance of this crab as shredder in subtropical streams and the effective nutrient assimilatizon of plant matter. The paucity of shredders in tropical (Dobson et al. 2002) and subtropical (Neiff and Poi de Neiff 1990; Ezcurra de Drago et al. 2007) zones suggested that the leaf processing could be done by alternative decomposition pathways, such as microbial activity, which is favored by higher temperatures (Irons et al. 1994). However, there is evidence that shredders are not scarce in these systems (Cheshire et al. 2005) and decapod crustaceans have been reported to bear a strong impact as macroconsumers on the leaf detritus processing (Mancinelli and Alessandro Scalzo 2013). In this way, T. kensleyi can play an important role in subtropical streams of southern South America influencing energy flow at multiple trophic levels.

The other issue is related to the effective assimilation of energy derived from vegetal matter. Plant litter is of 
Table 2 Items recorded in the stomach contents of Trichodactylus kensleyi sampled in streams of subtropical rainforest

\begin{tabular}{|c|c|}
\hline & Species \\
\hline \multicolumn{2}{|l|}{ Algae } \\
\hline \multirow[t]{4}{*}{ Euchlorophyceae } & Coelastrum sp. \\
\hline & Selenastrum sp. \\
\hline & Scenedesmus sp. \\
\hline & Ankistrodesmus sp. \\
\hline \multirow[t]{6}{*}{ Zygophyceae } & Staurastrum sp. \\
\hline & Zignema sp. \\
\hline & Cosmarium sp. \\
\hline & Euastrum sp. \\
\hline & Closterium sp. \\
\hline & Spirogyra sp. \\
\hline \multirow[t]{7}{*}{ Bacillariophyceae } & Navicula sp. \\
\hline & Chaetoceros sp. \\
\hline & Gyrosigma sp. \\
\hline & Cymbella sp. \\
\hline & Fragillaria sp. \\
\hline & Anphipleura sp. \\
\hline & Bacillaria sp. \\
\hline \multirow[t]{4}{*}{ Ulothricophyceae } & Basicladia sp. \\
\hline & Oedogonium sp. \\
\hline & Ulotrix sp. \\
\hline & Bulbochaeta sp. \\
\hline
\end{tabular}

\section{Vegetal remains \\ Fungi \\ Protozoa \\ Rotifera}

Oligochaeta

Crustacea

Cladocera

Copepoda: Calanoida

Nauplii

Ostracoda
Table 2 Items recorded in the stomach contents of Trichodactylus kensleyi sampled in streams of subtropical rainforest (Continued)

\author{
Insecta \\ Ephemeroptera \\ Trichoptera \\ Diptera \\ Chironomus sp.
}

Parachironomus sp.

Araneae

lower quality, contains a high proportion of fiber (cellulose and hemicellulose), has high C:N ratio, and typically contains secondary compounds such as tannins. On the other hand, cellulose is the major source of carbohydrates in the Earth, and traditionally, textbooks indicated non-animal organisms (e.g., bacteria and fungi) as the primary cellulase synthesizers. The widespread belief that animals cannot produce cellulase is now being rejected (Lo et al. 2003), and there are studies that prove the endogenous synthesis of these enzymes in decapods (Linton et al. 2006). The important amount of vegetal matter in the gut content of T. kensleyi implies some kind of metabolic way for the digestion of cellulose, either by an endogenous capacity or by carrying endosymbiotic organisms as reported for other crustaceans (Zimmer et al. 2001). The low nutritional quality of plant debris is known; however, it could be improved by the colonization of decomposer microorganisms after leaves have fallen (Nordhaus et al. 2006; Linton and Greenaway 2007). The high amount of vegetal matter ingested by $T$. kensleyi suggests a way to enhance the energy supply derived from a poor nutritional food. On the other hand, the high values of IRI

Brachionus sp

Keratella sp.

Diaphanosoma sp.

Daphnia sp.

Bosminopsis sp.

Ilyocryptus spiniger

Macrothrix sp.

Chydorus sp.

Notodiaptomus sp.

Diaptomus sp.

Bockella sp.

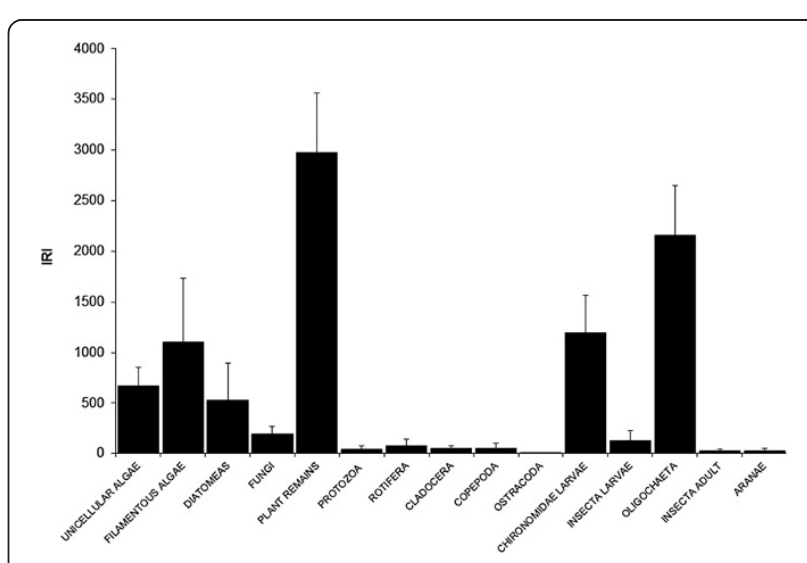

Figure 4 IRI of food items identified in all stomach contents of Trichodactylus kensleyi captured in subtropical streams. 

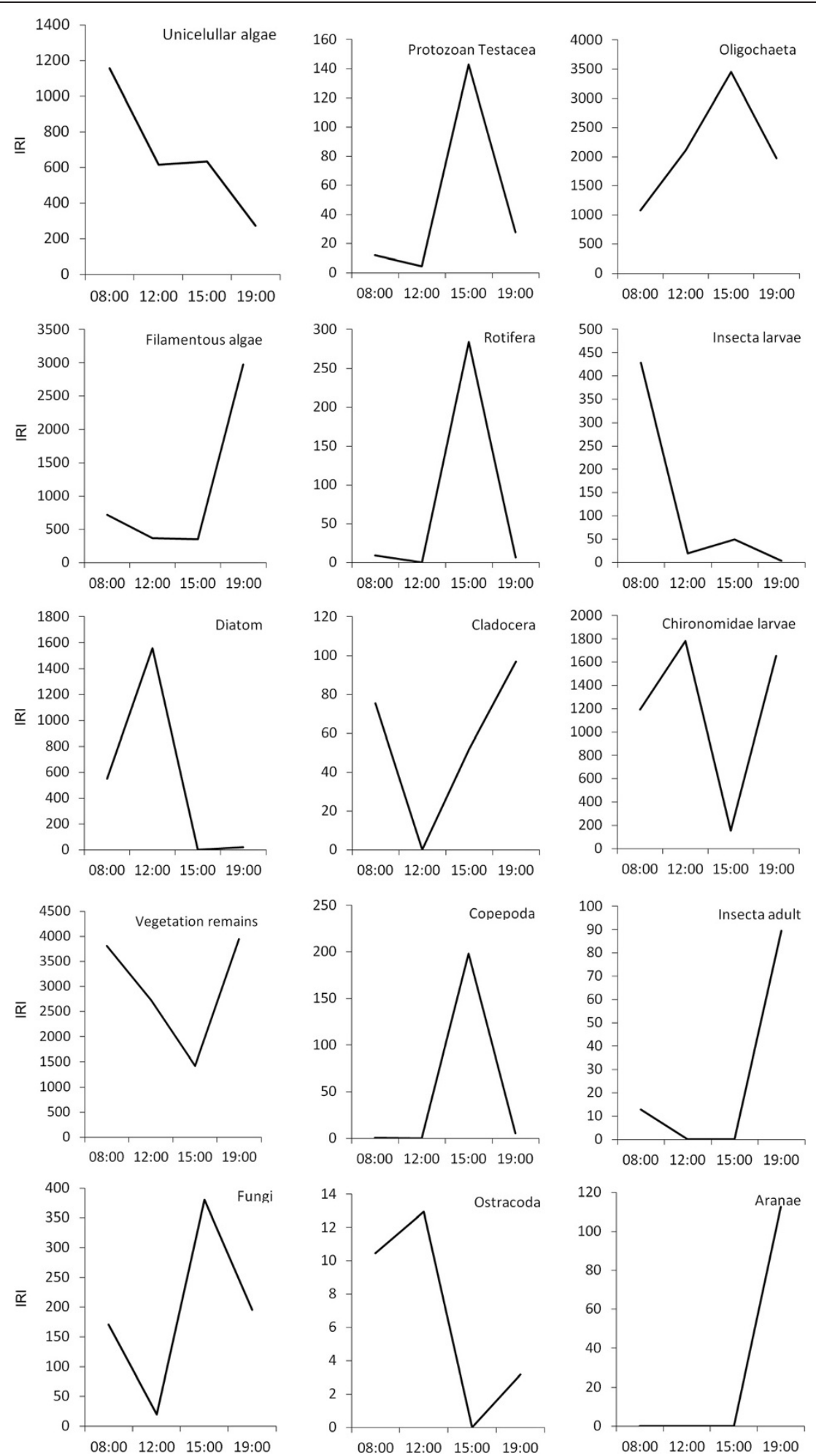

Figure 5 IRI of food items identified in stomach contents of Trichodactylus kensleyi at each sample hour.

could be masking the long time of digestion needed to process plant tissue, as suggested previously for Aegla platensis (Colpo et al. 2012).
Williner and Collins (2013) verified that adults of $T$. borellianus ate more vegetal components than juveniles. It is possible that the same may happen with 
T. kensleyi, since the average of cephalothorax width of specimens captured in this study corresponded to the adult specimens $(12.2 \pm 2.2 \mathrm{~mm})$. However, further studies of juveniles' diet are still necessary to corroborate this hypothesis. Juveniles need a protein-rich diet for growth while adult crabs require energy for maintenance, ingesting the poorest nitrogen food such as vegetal tissue (Mancinelli and Alessandro Scalzo 2013). In addition, T. kensleyi and T. borellianus are small-sized crabs, which implies a high metabolic rate than large species, requiring extracting more energy per unit of ingesta due to higher respiration losses (Mattson 1980). Then, this requirement is even higher in juveniles. In this way, the nutritional improvement of the diet should be supplied with nitrogen-rich food such as animal items and even algae.

Oligochaetes and chironomid larvae were the most important items in the diet of $T$. kensleyi following vegetal remains. In terms of nutritional content, oligochaetes and insect larvae contain a high proportion of protein relative to their biomass (Hepher 1989). In addition, these organisms are in general abundant in streams (Cushing and Allan 2001), indicating the opportunistic trophic behavior of this crab species. On the other hand, algae, another important item in the diet, are considered truly as the grasses of the stream waters and can be present in varying numbers and kinds attached to solid objects such as rocks (Cushing and Allan 2001). All these prey items, together with those of less relative importance in the diet (e.g., microcrustaceans, rotifers, and protozoans) should be nutritionally essential for the crabs' growth and reproduction, contributing with protein, lipid, vitamin, and mineral requirements. However, the ingestion of different kinds of food can be variable and modulated by endogenous factors and environmental influences (Aréchiga and Rodríguez-Sosa 1997). In this study, T. kensleyi showed moments of major trophic activity and uses different kinds of trophic sources throughout the day.

The diel rhythm of feeding activity of organisms is primarily a response to the most constant external stimulus, the light-dark phase. However, there are other ecological factors in nature, both positive and negative stimuli, which determine the temporal distribution of behavior patterns (Daan and Aschoff 2001). Some of the most adaptive temporal shift in the rhythm behavior is related to the coexistence of species and ecological interaction such as predation-prey systems and competition (Kronfeld-Schor and Dayan 2003). T. kensleyi co-exist in subtropical streams with other decapod anomurans such as Aegla singularis (Melo 2003). Both decapods are found in the stream bottom, under sediments and rocks, and have similar diet (Williner 2007), suggesting a potential niche overlap between these decapods. In this way, it is feasible to think that these sympatric species could facilitate the co-existence through the partitioning of time. However, this hypothesis is speculative since there is no additional information about the feeding activity of A. singularis, although studies of other aeglids propose a more nocturnal activity (Sokolowicz et al. 2007).

In $T$. kensleyi, the presence of full stomachs was registered throughout the day, but with a higher proportion during the early morning and late afternoon. This pattern is similar to other decapod species from inland waters, which indicates a crepuscular (dawn and dusk) feeding rhythm (Collins 1997; Williner and Collins 2002; Aguzzi et al. 2005; Zimmermann et al. 2009). However, there are many evidences that the presence of food at any time of the day can trigger the locomotion in decapod crustaceans even in periods of low activity (Fernandez de Miguel and Aréchiga 1994; Reigada 2002; Pontes and Arruda 2005; Sokolowicz et al. 2007; Zimmermann et al. 2009). Indeed, in T. kensleyi, the presence of prey items in the gut content suggests a continuous food intake and can provide clues of the movement of crabs in streams throughout the day.

As mentioned, higher proportion of full stomachs were registered at 8:00 and 19:00. In these moments, the presence of chironomid larvae, vegetal remains, unicellular green algae, and diatoms was more abundant in the early morning while oligochaetes and meiofauna organisms (e.g., protozoans, rotifers, copepods, cladocerans) reach higher IRI values during the dusk period. Chironomidae genera (Chironomus Meigen and Parachironomus Lenz), identified in crabs' gut contents, are categorized as gathererscollectors. Oligochaetes also belong to this functional feeding group (Zilli et al. 2008). These benthic organisms are commonly found within the sediment or above stones where they obtain their food, collecting fine particulate organic matter (FPOM) in deposit zones and under rocks (Cushing and Allan 2001). In this way, it is possible to infer that T. kensleyi foraged mainly these zones during crepuscular hours. During the forage of these areas, crabs could ingest meiofauna together with the ingestion of sand and sediment particles in the stream bottom. In the dawn period, the ingestion of algae might be indirectly related to the cropping of vegetal debris, since the algae identified were mainly periphytic and benthic (Vélez and Maidana 1995). On the other hand, algae could be actively consumed by the grasping of rocks. The consumption of food during those moments of lower activity (midday and afternoon) could be related to the availability of such items nearby shelter sites. When analyzing consumer relations, it is relevant also to delve into those unexplored as may be facilitating habitat (Hart and Marshall 2013). This type of interaction has been registered in the anomuran $A$. uruguayana (Schmitt 1942), wherein the step of diatoms to the digestive tract results in an increase in their rate of reproduction (Devercelli and Williner 2006). 
Although results suggest general movements during feeding activity, there are some factors that could influence the evaluation of the effective trophic spectrum and the exact moment when each kind of food was ingested. Initially, brachyuran decapods have the most complex foregut armature with a robust gastric mill (Icely and Nott 1992) that contributes to an efficient trituration process and, consequently, difficult gut content identification. In addition, the residence time can vary greatly according to the type of food (McGaw and Curtis 2013). For example, the complete gut clearance of prey such as oligochaetes and dipteran larvae could lead at least $10 \mathrm{~h}$ at $21^{\circ} \mathrm{C}$ in Macrobrachium borellii (Nobili, 1896), a caridean freshwater prawn (Carvalho et al. 2011). However, the absence of a robust gastric armature in caridean prawns implies that crabs may have a lesser time of foregut evacuation. Digestive efficiency is ultimately influenced by transit times and tends to be higher in diets composed of animal items than in those based on vegetable matter (McGaw and Curtis 2013). This leads to an underestimation of prey with rapid digestion, like those of soft body, and an overestimation of those with slow digestion, like plant debris.

\section{Conclusions}

There are many biological and ecological aspects of crustacean decapods that still must be studied for a better understanding of their role in freshwater systems. This research provides knowledge that complements previous studies about trophic relationships of trichodactylid crabs. The generalist and opportunistic trophic behavior together with the carnivore and shredder feeding habitats indicates that $T$. kensleyi directs the flow of energy and matter from benthic community and riparian sources to superior trophic levels using both macroand microfauna.

\section{Competing interests}

The authors declare that they have no competing interests.

\section{Authors' contributions}

WW and PAC designed the study. PAC participated in the field trips for sampling. WW and PAC carried out the laboratory analyses and data analyses. DAC made the figures and wrote the manuscript. WW, DAC, and PAC made intellectual contributions and reviewed the manuscript. All authors read and approved the final manuscript.

\section{Acknowledgements}

This work was supported by grant CAI + D 2011 PI 119.

\footnotetext{
Author details

${ }^{1}$ Instituto Nacional de Limnología (CONICET-UNL), Ciudad Universitaria, Paraje El Pozo s/n, Santa Fe 3000, Argentina. ${ }^{2}$ Facultad de Humanidades y Ciencias (UNL), Ciudad Universitaria, Paraje El pozo s/n, Santa Fe 3000, Argentina. ${ }^{3}$ Facultad de Bioquímica y Ciencias Biológicas (UNL), Ciudad Universitaria, Paraje El pozo s/n, Santa Fe 3000, Argentina.
}

Received: 28 May 2014 Accepted: 10 September 2014

Published online: 22 September 2014

\section{References}

Aguzzi J, Cuesta JA, Librero M, Toja J (2005) Daily and seasonal feeding rhythmicity of Palaemonetes varians (Leach 1814) from southwestern Europe. Mar Biol 148:141-147

Aréchiga H, Rodríguez-Sosa L (1997) Coupling of environmental and endogenous factors in the control of rhythmic behavior in decapod crustaceans. J Mar Biol Ass UK 77:17-29

Balasubramanian CP, Suseelan C (1998) Natural diet of the deep water crab Charybdis smithii McLeay (Brachyura: Portunidae) of the sea around India. Indian J Fish 45:407-411

Beltzer AH, Paporello G (1984) Alimentación de aves en el valle aluvial del río Paraná. IV Agelaius cyanopus cyanopus Viellot, 1819 (Passeriformes: Icteridae). Iheringia Ser Zool 62:55-60

Beltzer AH (1983) Nota sobre fidelidad y participación trófica del "biguá común" (Phalacrocorax olivaceus) en ambientes del rio Paraná medio (Pelecaniformes: Phalacrocoracidae). Rev Asos Cienc Nat Lit 14:47-52

Beltzer AH (1984) Ecología alimentaria de Aramides ypecaha (Aves: Rallidae) en el valle aluvial del río Paraná medio (Argentina). Rev Asos Cienc Nat Lit 16:73-83

Bianchini JJ, Delupi LH (1993) Fauna de Agua Dulce de la República Argentina. Mammalia, vol 44. PROFADU, Buenos Aires

Bonetto AA, Pignalberi C, Cordiviola E (1963) Ecología alimentaria del amarillo y moncholo, Pimelodus clarias (Bloch) y Pimelodus albicans (Valenciennes). Physis 24:87-94

Burress ED, Gangloff MM, Siefferman L (2013) Trophic analysis of two subtropical South American crabs using stable isotope ratios. Hydrobiologia 702:5-13

Cannicci S, Dahdouh-Guebas AD, Vannini M (1996) Natural diet and feeding habits of Thalamita crenata (Decapoda: Portunidae). J Crust Biol 16:678-683

Carvalho DA, Collins PA, De Bonis CJ (2011) Gut evacuation time of Macrobrachium borellii (Caridea: Palaemonidae) feeding on three types of prey from the littoral-benthic community. J Crust Biol 31:630-634

Carvalho DA, Collins PA, De Bonis CJ (2013a) Predation ability of freshwater crabs: age and prey-specific differences in Trichodactylus borellianus (Brachyura: Trichodactylidae). J Freshwater Ecol 28:573-584

Carvalho DA, Collins PA, De Bonis CJ (2013b) The diel feeding rhythm of the freshwatercrab Trichodactylus borellianus (Decapoda: Brachyura) in mesocosm and natural conditions. Mar Freshw Behav Phy 46:89-104

César II, Armendáriz LC, Becerra RV, Liberto R (2004) Biodiversidad de Crustácea (Anostraca, Notostraca Spinicaudata, Laevicaudata, Ostracoda, Amphipoda y Brachyura Trichodactylidae) de la Mesopotamia argentina. INSUGEO Miscelánea 12:247-252

Cheshire K, Boyero L, Pearson R (2005) Food webs in tropical Australian streams: shredders are not scarce. Freshwater Biol 50:748-769

Collins PA (1997) Ritmo diario de alimentación en el camarón Macrobrachium borellii (Decapoda, Palaemonidae). Iheringia Ser Zool 82:19-24

Collins PA (2005) Distribución altitudinal del cangrejo Trichodactylus kensleyi (Rodríguez, 1992) en Misiones, Argentina. Nat Neotropicalis 36:85-87

Collins PA, Williner V, Giri F (2006) Trophic relationships in Crustacea Decapoda of a river with floodplain. In: Elewa AMT (ed) Predation in Organisms: A Distinct phenomenon. Springer, Heidelberg

Collins PA, Williner V, Giri F (2007) Littoral communities: macrocrustaceans. In: Iriondo MH, Parma de Croux MJ, Paggi JC (ed) The Middle Paraná River: limnology of a subtropical wetland. Springer, Berlin

Colpo KD, Ribeiro LC, Wesz B, Ribeiro LO (2012) Feeding preference of the South American endemic anomuran Aegla platensis (Decapoda, Anomura, Aeglidae). Naturwissenschaften 99:333-336

Colwell RK (2013) Estimates: statistical estimation of species richness and shares species for samples. Version 9. University of Connecticut, Connecticut

Cushing CE, Allan JD (2001) Streams: their ecology and life. Academic Press, Hong Kong

Daan S, Aschoff J (2001) The entrainment of circadian systems. In: Takahashi JS, Turek FW, Moore RY (ed) Handbook of Behavioral Neurobilogy: Circadian Clocks, vol 12. Kluwer Academic/Plenum Publishers, New York, pp 7-43

Devercelli M, Williner V (2006) Diatom grazing by Aegla uruguayana (Decapod: Anomura: Aeglidae): digestibility and cell viability after gut passage. Ann Limnol Int J Lim 42:73-77

Dobson M, Magana A, Mathooko JM, Ndegwa FK (2002) Detritivores in Kenyan highland streams: more evidence for the paucity of shredders in the tropics? Freshwater Biol 47:909-919 
Dumont HJ, Van de Velde I, Dumont S (1975) The dry weight estimate of biomass in a selection of Cladocera, Copepoda and Rotifera form the plankton, periphyton and benthos of continental waters. Oecologia 19:75-97

Edmonson WF, Winberg GG (1971) A manual for the assesment of secondary productivity in fresh waters. Blackwell, Oxford

Ezcurra de Drago I, Marchese M, Montalto L (2007) Benthic invertebrates. In: Iriondo MH, Parma de Croux MJ, Paggi JC (ed) The Middle Paraná River: Limnology of a Subtropical Wetland. Springer, Berlin

Fernandez de Miguel F, Aréchiga H (1994) Circadian locomotor activity and its entrainment by food in the crayfish Procambarus clarkii. J Exp Biol 190:9-21

Freire J (1996) Feeding ecology of Liocarcinus depurator (Decapoda: Portunidae) in the Ria de Arousa (Galicia, north-west Spain): effects of habitat, season and life history. Mar Biol 126:297-311

Frick MG, Kopitsky K, Bolten AB, Bjorndal KA, Martins HR (2001) Sympatry in grapsoid crabs (genera Planes and Plagusia) from olive ridley sea turtles (Lepdochelys olivacea), with descriptions of crab diets and masticatory structures. Mar Biol 158:1699-1708

Hart SP, Marshall DJ (2013) Environmental stress, facilitation, competition, and coexistence. Ecology 94:2719-2731

Hepher B (1989) Principles of fish nutrition. In: Shilo M, Sargig S (ed) Fish culture in warm water systems: problems and trends. CRC Press, Boca Raton

Icely JD, Nott JA (1992) Digestion and absorption: digestive system and associated organs. In: Harrison FW, Humes AG (ed) Microscopic Anatomy of Invertebrates: Decapod Crustacea, vol 10. Wiley-Liss, New York, pp 146-201

Irons JG, Oswood MW, Stout RJ, Pringle CM (1994) Latitudinal patterns in leaflitter breakdown: is temperature really important. Freshwater Biol 32:401-411

Josileen J (2011) Food and feeding of the blue swimmer crab, Portunus pelagicus (Linnaeus, 1758) (Decapoda, Brachyura) along the coast of Mandapam, Tamil, Nadu, India. Crustaceana 84:1169-1180

Kratina P, Lecraw RM, Ingram T, Anholt BR (2012) Stability and persistence of food webs with omnivory: is there a general pattern? Ecosphere 3(6):1-18

Kronfeld-Schor N, Dayan T (2003) Partitioning of time as an ecological resource. Annu Rev Ecol Evo S 34:153-181

Lajmanovich RC, Beltzer AH (1993) Aporte al conocimiento de la biología alimentaria de la pollona negra (Gallinula chloropus) en el Paraná medio, Argentina. El Hornero 13:289-291

Linton SM, Greenaway P (2007) A review of feeding and nutrition of herbivorous land crabs: adaptations to low quality plant diets. J Comp Physiol B 177:269-286

Linton SM, Greenaway P, Towle DW (2006) Endogenous production of endo- $\beta-1$, 4-glucanase by decapod crustaceans. J Comp Physiol B 176:339-348

Long ZT, Bruno JF, Duffy JE (2011) Food chain length and omnivory determine the stability of a marine subtidal food web. J Anim Ecol 80:586-594

Lo N, Watanabe H, Sugimura M (2003) Evidence for the presence of a cellulase gene in the last common ancestor of bilaterian animals. Proc R Soc Lond B Biol Sci 270:69-72

López LA, Arias MM, Peltzer PM, Lajmanovich RC (2005) Dieta y variación morfométrica de Leptodactylus ocellatus (Linnaeus, 1758) (Anura: Leptodactylidae) en tres localidades del centro-este de Argentina. Bol Asoc Herpetol Esp 16:32-39

Lopretto EC (1976) Morfología comparada de los pleópodos sexuales masculinos en los Trichodactylidae de la Argentina (Decapoda, Brachyura). Limnobios 1:67-94

Magalhães C (2003) Famílias Pseudothelphusidae e Trichodactylidae. In: Melo GAS (ed) Manual de identificação dos crustáceos decápodos de água doce do Brasil. Editora Loyola, São Paulo

Mancinelli G, Alessandro Scalzo FS (2013) The effects of decapod crustacean macroconsumers on leaf detritus processing and colonization by invertebrates in stream habitats: a meta-analysis. Int Rev Hydrobiol 98:206-216

Mantelatto FLM, Christofeletti RA (2001) Natural feeding activity of the crab Callinectes ornatus (Portunidae) in Ubatuba Bay (São Paulo, Brazil): influence of season, sex, size and molt stage. Mar Biol 138:585-594

Mantelatto FLM, Petracco M (1997) Natural diet of the crab Hepatus pudibundus (Brachyura: Calappidae) in Fortaleza bay, Ubatuba (SP), Brazil. J Crustacean Biol 17:40-446

Massoia E (1976) Fauna de Agua Dulce de la República Argentina. Mammalia, vol 44. Imprenta Coni, Buenos Aires

Mattson WJ (1980) Herbivory in relation to plant nitrogen content. Annu Rev Ecol Syst 11:119-161

McGaw IJ, Curtis DL (2013) A review of gastric processing in decapod crustaceans. J Comp Physiol B 183:443-465
Melo GAS (2003) Manual de Identificação dos Crustáceos Decapoda de Água Doce do Brasil. Edições Loyola, São Paulo

Myers N, Russell A, Mittermeier C, Mittermeier G, da Fonseca G, Kent J (2000) Biodiversity hotspots for conservation priorities. Nature 403:853-858

Neiff JJ, Poi de Neiff A (1990) Litterfall, leaf decomposition and litter colonization of Tessaria integrifolia (Compositae) in the Paraná River floodplain. Hydrobiologia 203:45-52

Nordhaus I, WolV M, Diele K (2006) Litter processing and population food intake of the mangrove crab Ucides cordatus in a high intertidal forest in northern Brazil. Estuar Coast Shelf Sci 67:239-250

Pinkas L, Olipham MS, Iversor ILK (1971) Food habits of albacore, bluefin tuna and bonito in California waters. Fish Bull 152:1-105

Pirela R, Rincón J (2013) Dieta del cangrejo dulceacuícola Bottiella niceforel (Schmitt and Pretzmann, 1968) (Decapoda: Trichodactylidae) y su relación con el procesamiento de la materia orgánica en una corriente intermitente del noroeste de Venezuela. Lat Am J Aquat Res 41:696-706

Pontes CS, Arruda MF (2005) Comportamento de Litopenaeus vannamei (Boone) (Crustacea, Decapoda, Penaeidae) em função da oferta do alimento artificial nas fases clara e escura do período de 24 horas. Rev Bras Zool 22:648-652

Reigada ALD (2002) Diel activity rhythm in Callinectes ornatus Ordway, 1863 and Callinectes danae Smith, 1869 (Brachyura, Portunidae) under laboratory conditions. In: Escobar-Briones E, Alvarez F (ed) Modern approaches to the study of Crustacea. Kluwer Academic, Norwell, pp 915-920

Ruttner-Kolisko A (1977) Suggestions for biomass calculation of plankton rotifers. Arch Hydrobiol 8:71-76

Sokolowicz C, Ayres-Peres L, Santos S (2007) Atividade nictimeral e tempo de digestão de Aegla longirostri (Crustacea, Decapoda, Anomura). Iheringia Ser Zool 97:235-238

Vélez CG, Maidana NI (1995) Algae. In: Lopretto E, Tell G (ed) Ecosistemas de aguas continentales. Ediciones Sur, La Plata, pp 379-442

Wear RG, Haddon M (1987) Natural diet of the crab Ovalipes catharus (Crustacea Portunidae) around central and northern New Zealand. Mar Ecol Prog Ser 35:39-49

Williner V, Collins PA (2002) Variación espacio-temporal de la actividad del camarón dulciacuícola Macrobrachium jelskii (Miers, 1877) (Crustacea, Decapoda, Caridea, Palaemonidae). Ecol Aust 12:3-10

Williner V, Collins PA (2013) Feeding ecology of the freshwater crab Trichodactylus borellianus (Decapoda: Trichodactylidae) in the floodplain of the Paraná River, Southern South America. Lat Am J Aquat Res 41:781-792

Williner V (2007) Ecología trófica de poblaciones de especies de la familia Aeglidae en la Argentina. Universidad Nacional de La Plata, Dissertation

Woodward G (2009) Biodiversity, ecosystem functioning and food webs in fresh waters: assembling the jigsaw puzzle. Freshwater Biol 54:2171-2187

Zar JH (1996) Biostatistical analysis. Prentice Hall, New York

Zilli FL, Montalto L, Marchese MR (2008) Benthic invertebrate assemblages and functional feeding groups in the Paraná River floodplain (Argentina). Limnologica 38:159-171

Zimmer M, Danko JP, Pennings SC, Danford AR, Ziegler A, Uglow RF, Carefoot TH (2001) Hepatopancreatic endosymbionts in coastal isopods (Crustacea: Isopoda), and their contribution to digestion. Mar Biol 138:955-963

Zimmermann BL, Aued AW, Machado S, Manfio D, Scarton LP, Santos S (2009) Behavioral repertory of Trichodactylus panoplus (Crustacea: Trichodactylidae) under laboratory conditions. Zoology 26:5-11

\section{doi:10.1186/s40555-014-0071-x}

Cite this article as: Williner et al.: Feeding spectra and activity of the freshwater crab Trichodactylus kensleyi (Decapoda: Brachyura: Trichodactylidae) at La Plata basin. Zoological Studies 2014 53:71. 